\title{
Diplomasi Yayasan Sukma dalam Negosiasi Pembebasan Sandera Warga Negara Indonesia di Filipina Selatan
}

Joshua Hasan Sidik

Program Studi Hubungan Internasional, Universitas Padjadjaran, Indonesia; rachmanjoshua@ gmail.com

Departemen Hubungan Internasional, Universitas Padja djaran, Indonesia; hasan.sidik@unpad.ac.id

| submit:26-08-2020 | accept: 25-01-2021

| publish: 31-01-2021

\section{Keywords}

Sukma Foundation, Multi-track

diplomacy, Hostage-Release Negotiation, Abu Sayyaf Group

\section{Kata Kunci}

Diplomasi multi-track, Kelompok Abu Sayyaf, Negosiasi Pembebasan Sandera, Yayasan Sukma

\begin{abstract}
This research explains the activity of Sukma Foundation in the South Philippines in order to release 10 Indonesian hostages. The concepts used by the researcher to explain this phenomenon are multi-track diplomacy, conflict escalation, and hostage-release negotiation. Using qualitative-descriptive approach through interviews, literature studies, and internerbased research, researcher find that multi-track diplomacy, which involving humanity and cultural approaches, was the main factor of the 10 Indonesian hostages-release negotiation. This research also describes the escalation happened during the hostage-release process.
\end{abstract}

\section{ABSTRAK}

Penelitian ini menjelaskan aktivitas yang dilakukan Yayasan Sukma hingga ke sepuluh sandera WNI di Filipina Selatan dapat dibebaskan. Untuk menjelaskan aktivitas Yayasan Sukma dalam pembebasan 10 sandera WNI di Filipina Selatan, penelitian menggunakan konsep multi-track diplomacy, eskalasi konflik, serta negosiasi pembebasan sandera. Peneliti menggunakan pendekatan kualitatif-deskriptif dengan teknik pengumpulan data berupa wawancara, studi pustaka, serta penelitian berbasis daring. Penelitian ini menemukan bahwa multi-track diplomacy yang melibatkan pendekatan kemanusiaan dan kebudayaan menjadi kunci keberhasilan terbebasnya 10 WNI yang disandera oleh Kelompok Abu Sayyaf. Penelitian ini juga mendeskripsikan proses eskalasi yang terjadi sela ma upaya pembebasan sandera berlangsung. 


\section{PENDAHULUAN}

Pada tanggal 26 Maret 2016, kasus penyanderaan menimpa 10 Warga Negara Indonesia (WNI). Peristiwa bermula saat kapal tunda Brahma 12 dan kapal tongkang An and 12 yang berbendera Indonesia dibajak oleh Kelompok Abu Sayyaf saat sedang berlayar di Sungai Puting, Kalimantan Selatan menuju Batangas, Filipina Selatan. Sebanyak 10 WNI yang menjadi anak buah kapal (ABK) di kedua kapal pun kemudian disandera oleh kelompok gerakan separatis Abu Sayyaf. Untuk membebaskan kesepuluh WNI tersebut, Kelompok Abu Sayyaf menuntut 50 juta Peso atau sekitar 15 milyar Rupiah sebagai uang tebusan dengan tenggat waktu hingga 8 April 2016. ${ }^{1}$ Pemerintah Indonesia melalui Kementerian Luar Negeri serta Kedutaan Besar Republik Indonesia di Manila kemudian terus melakukan upaya pembebasan sandera. Meski Tentara Nasional Indonesia (TNI) mengaku siap menjalankan operasi khusus guna membebaskan sandera, pada akhirnya pendekatan kemanusiaan lebih diutamakan. Salah satu alasan mengenai dipilihnya pendekatan kemanusiaan adalah adanya kemiripan latar belakang agama dan budaya masyarakat Filipina Selatan dengan Indonesia. Setelah menempuh berbagai upaya, pada tanggal 12 Mei 2016 Indonesia berhasil 10 ABK Warga Negara Indonesia berhasil dibebaskan.

Peristiwa tersebut mendapatkan perhatian setelah 10 ABK WNI dibebaskan tanpa ada kontak senjata juga klaim dari Kementerian Luar Negeri Republik Indonesia bahwa pembebasan dilakukan tanpa uang tebusan. ${ }^{2}$ Sebab penyanderaan, yang dapat dipandang

${ }^{1}$ BBC. Dua kapal Indonesia dibajak di Filipina, 10 WNI disandera. Melalui <http://www.bbc.com/indonesia/berita_indonesia/ 2016/03/160329_indonesia_kapal_dibajak_filipin a $>[03 / 9 / 19]$

2 Wangke, Humphrey. 2016. "Keberhasilan Diplomasi Total". Majalah Info Singkat Hubungan Internasional (May). Melalui http://berkas.dpr.go.id/puslit/files/info singkat/In fo\%20Singkat-VIII-10-II-P3DI-Mei-2016-4.pdf [03/9/19] sebagai konflik, seringkali ditanggapi dengan penggunaan kekerasan. Konflik sendiri didefinsikan oleh Zartmann dapat terjadi ketika terdapat dua atau lebih pihak memiliki perbedaan pandangan dan berusaha memaksakan kehendak mereka. ${ }^{3}$ Namun, dalam upayanya menyelesaikan konflik dengan Kelompok Abu Sayyaf, Indonesia tidak menggunakan kekerasan, melainkan menggunakan pendekatan kemanusiaan.

Dalam perkembangannya, konflik cenderung berujung pada kekerasan. Berkaitan dengan penelitian ini, konflik yang mana adalah penyanderaan, dilakukan oleh kelompok teroris. Dalam arti luas, terorisme merujuk pada upaya untuk mencapai sebuah tujuan politik dengan menggunakan kekerasan untuk memunculkan rasa takut, khawatir, d an ketidakpastian. ${ }^{4}$ Dengan premis tersebut, maka terorisme dapat diartikan sebagai sebuah taktik perang. Mengingat terorisme berupaya mencapai sebuah tujuan politik dengan menggunakan kekerasan, maka tindak terorisme merupakan sebuah konflik kekerasan. ${ }^{5}$

Sedangkan, peacemaking yang dalam penelitian ini adalah pembebasan sandera seperti diungkapkan oleh Louise Diamond dan John McDonald melalui buku Multi Track Diplomacy: A System Approach to Peace, adalah serangkaian tindakan yang tidak hanya berupaya untuk mewujudkan perdamaian diantara pihak yang sedang berlawanan, melainkan juga untuk mencegah, untuk mengelola dan meresolusi konflik, untuk rekonsiliasi, untuk mengeksplorasi isu terkait perdamaian umum maupun kasus konflik khusus, untuk mendidik dan meneliti isu perdamaian dan konflik khusus, untuk membangun teori dan praktek langsung, untuk mempengaruhi kebijakan, untuk menyediak an

\footnotetext{
3 Zartmann, I. \& Faure, G. 2005. Escalation and Negotiation in International Conflicts. New York: Cambridge University Press, 4.

4 Heywood, A. 2011. Global Politics. London: Palgrave Macmillan. 284.

5 Goodin, R. 2006. What's Wrong with Terrorism. Cambridge: Polity. 5.
} 
informasi, untuk memfasilitasi dialog, untuk menyelenggarakan negosiasi dan mediasi, yang mana semua tindakan tersebut didasari dan ditujukan untuk membangun hubungan yang lebih baik, baik antara Negara dengan Negara maupun dengan masyarakat. ${ }^{6}$ Dalam rangka membebaskan sandera, negosiator memerlukan motif dan latar belakang dari pihak yang akan diajak bernegosiasi.

Kelompok Abu Sayyaf sendiri adalah sebuah kelompok jihadis militan dan perompak yang beroperasi di wilayah Filipina Selatan. Sebagai upayanya untuk membebaskan WNI dari penyanderaan Abu Sayyaf, Indonesia kemudian melibatkan beberapa aktor seperti Yayasan Sukma. Diplomasi yang dilakukan oleh Yayasan Sukma dalam membebaskan sandera, sebagai turunan dari multi-track diplomacy, adalah sebuah bentuk modern diplomacy dimana terdapat beberapa aktor yang terlibat.

Dalam upayanya membebaskan sandera, Yayasan Sukma menggunakan pendekatan agama dan budaya. Pendekatan kemanusiaan dengan unsur budaya dan agama oleh Yayasan Sukma tersebut kemudian berhasil membebaskan 10 WNI yang menjadi korban tindak terorisme kelompok Abu Sayyaf. Dengan keberhasilan tersebut, pendekatan budaya dan agama oleh Yayasan Sukma berpotensi menjadi percontohan bagi negara lain sebagai solusi. Selain konsep multi-track diplomacy, penelitian juga menggunakan konsep pembebasan sandera melalui negosiasi oleh I. William Zartmann dan Guy Olivier Faure.

\section{KERANGKA KONSEPTUAL}

\section{Multi-track Diplomacy}

Cikal bakal multi-track diplomacy berawal dari tahun 1981, melalui artikel yang ditulis oleh Joseph Montvile mengenai konsep diplomasi track satu dan track dua.

\footnotetext{
${ }^{6}$ Diamond, L \& McDonald, J. 1996. Multi Track Diplomacy: A System Approach to Peace. Colorado: Kumarian Press. 13.
}

Tabel 1. Diplomasi Track Satu dan Dua

\begin{tabular}{|l|l|l|}
\hline Aktor & Track satu & Track dua \\
& $\begin{array}{l}\text { Negara, pemerintah, } \\
\text { organisasi } \\
\text { multinasional, } \\
\text { pemimpin Negara } \\
\text { dan pemimpin } \\
\text { organisa si } \\
\text { multinasional }\end{array}$ & $\begin{array}{l}\text { Perwakilan tidak } \\
\text { resmi, organisasi } \\
\text { non-pemerintah } \\
\text { (NGO), } \\
\text { pemimpin lokal, } \\
\text { kelompok akar } \\
\text { rumput }\end{array}$ \\
\hline Metode & $\begin{array}{l}\text { Insentif positif dan } \\
\text { negatif, mediasi, } \\
\text { dukungan ekonomi, } \\
\text { dukungan politik }\end{array}$ & $\begin{array}{l}\text { Diskusi dua } \\
\text { arah, workshop, } \\
\text { rekonsiliasi akar } \\
\text { rumput }\end{array}$ \\
\hline Fokus & $\begin{array}{l}\text { Peacemaking dan } \\
\text { Peacekeeping }\end{array}$ & $\begin{array}{l}\text { Peacemaking } \\
\text { dan } \\
\text { Peacebuilding }\end{array}$ \\
\hline
\end{tabular}

Sumber: Dewi, P. R., 2019: 193

Pada tabel 1 di atas, upaya diplomasi y ang dilakukan oleh track dua penting dilakukan guna melancarkan jalan bagi diplomasi y ang dilakukan oleh kategori satu. Hal ini dikarenakan track dua melakukan diplomasinya dengan terjun langsung ke arena konflik dan oleh karenanya informasi lebih mudah dikumpulkan.

Selanjutnya Louise Diamond dan John W. McDonald pada tahun 1989, Louise Diamond dan John McDonald melalui buku Multi-track Diplomacy: A Systems Approach to Peace, melahirkan perkembangan terakhir dari multitrack diplomacy sebagai pendekatan sistemik dalam peacemaking dan resolusi konflik y ang dikenal saat ini. Terdapat sembilan track dalam multi-track diplomacy. ${ }^{7}$ Berbeda dengan diplomasi tradisional yang lebih fokus pada pada penyelesaian konflik dan kekerasan, multi-track diplomacy fokus pada pencegah an konflik, seperti kemiskinan, atau pembangunan ulang perspektif. ${ }^{8}$ Dalam konteksnya dengan fenomena peny and eraan oleh Kelompok Abu Sayyaf, multi-track diplomacy sejatinya berpotensi untuk mengurangi kemiskinan, membangun ulang perspektif yang ada pada para anggota Kelompok Abu Sayyaf, hingga mencegah

\footnotetext{
${ }^{7}$ Institute for Multi-Track Diplomacy. 2006. Annual Report 2006. Arlington: 2.

${ }^{8}$ McDonald, J. 2012. The Institute for Multi-Track Diplomacy. Journal of Conflictology 3: 67.
} 
konflik yang ada di wilayah Filipina Selatan pada masa mendatang. Meski aktor nonpemerintah terus bertambah dalam hubungan internasional, namun pemerintah tetap memegang peranan terpenting dalam multitrack diplomacy. Melalui track satu ini, diplomasi resmi, policymaking, dan peacebuilding melalui aspek formal dilaksanakan. Pemerintah merupakan aktor dalam track satu. Selanjutnya, pada track dua adalah peacemaking through conflict resolution. Aktor dalam track dua ini adalah tenaga profesional di bidang resolusi konflik.

Pada track tiga adalah peacemaking through commerce. Melalui jalur ini manajemen konflik dapat terpengaruhi melalui aktivitas bisnis. Aktor dalam track tiga ad alah pelaku bisnis. Berikutnya track empat ad alah peacemaking through personal involvement. Aktor dalam track empat adalah warga negara sipil. Selanjutnya track lima adalah peacemaking through learning. Aktor dalam track lima adalah akademisi seperti penelitian, trainer, dan educator. Selanjutnya, track enam adalah peacemaking through advocacy. ${ }^{9}$ Aktor dalam track ini adalah aktivis. Dalam track ini terdapat aktivisme di bidang perdamaian $\mathrm{d}$ an lingkungan.

Berikutnya, track tujuh, adalah peacemaking through faith in action.${ }^{10}$ Aktor dalam track tujuh adalah pemuka agama dan penganutnya. Selanjutnya adalah peacemaking through providing resources dalam track delapan. Track ini merujuk kepada pemberian bantuan finansial untuk berbagai aktivitas yang dilakukan track lain. Aktor dalam track delapan adalah komunitas pendanaan serta filantropis.

Track terakhir, track sembilan, adalah peacemaking through information. Track terakhir ini berfungsi untuk membentuk opini publik. Aktor dalam track sembilan adalah orang-orang yang bekerja di area opini publik dan komunikasi.

\footnotetext{
${ }^{9}$ Diamond, L \& McDonald, J. Op. Cit. 87.

${ }^{10}$ Idem., 97.
}

Gambar 1. Multi-track Diplomacy

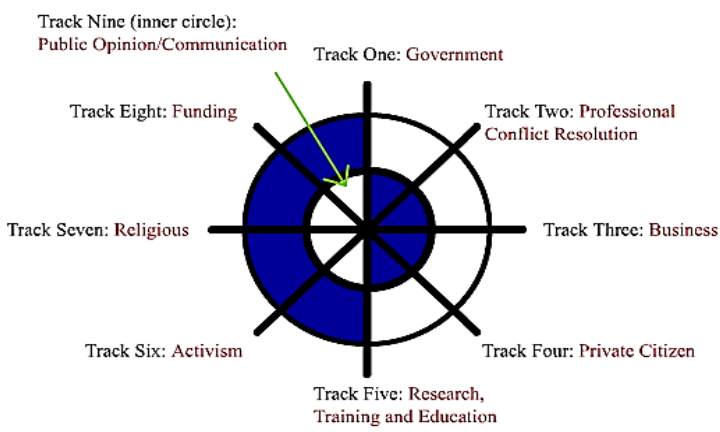

Sumber: John W. McDonald, 2003: 1

Sifat dan Penyebab, Eskalasi, De-eskalasi dan Negosiasi dalam Konflik Internasional Guna membebaskan sandera, negosiasi dipandang sebagai salah satu upaya paling efektif. Dalam upayanya membebaskan sandera, negosiator harus mengelola dua kendala yang saling bertentangan, yakni memastikan pembebasan sandera dan memberikan efek jera kepada teroris lain ny a agar penyanderaan tidak terulang. ${ }^{11}$ Mengingat negosiasi adalah akhir dari sebuah eskalasi konflik, maka penting untuk memahami eskalasi itu sendiri. Eskalasi dapat dipahami sebagai mekanisme koersif mutual yang lekat pada perspektif konflik. ${ }^{12}$

Namun eskalasi bukan hanya intensifikasi dari konflik di mana perubahan hanya terjadi pada tingkatan konflik, melainkan bentuk perubahan nature dari konflik itu sendiri. Oleh karenanya eskalasi dapat memengaruhi bahkan mengubah dimensi-dimensi dari konflik itu sendiri. Terdapat beberapa jenis eskalasi konflik, sebagai berikut:

1. Escalation of means

2. Escalation of ends

3. Escalation of space

4. Escalation of price

5. Escalation of parties

6. Escalation of images

7. Escalation of risk

11 Wilson, M. 2000. Toward a Model of Terrorist Behavior in Hostage-Taking Incidents. The Journal of Conflict Resolution 44: 406

12 Zartmann, I. \& Faure, G. 2005. Escalation and Negotiation in International Conflicts. New York: Cambridge University Press, 4. 


\section{Escalation of costs}

9. Escalation of commitment ${ }^{13}$

Dengan adanya eskalasi dalam sebuah konflik, maka akan meningkatkan "pertaruhan" yang ada. Jenis eskalasi yang terjadi dalam konflik akan menentu kan jenis solusi dan taktik yang akan diterapkan. Penyebab eskalasi konflik sendiri selain disebabkan oleh pihak yang terlibat, juga disebabkan oleh konflik itu sendiri. Sedangkan pihak-pihak yang terlibat dalam konflik memiliki beberapa tujuan dari eskalasi konflik, yaitu:

1. Memenangkan konflik;

2. Menghindari kekalahan, baik dengan mempertahankan konflik maupun mempercepat negosiasi;

3. Menutupi biaya hangus akibat konflik;

4. Mendapatkan dukungan, baik dari dalam maupun dari luar;

5. Merebut kesempatan;

6. Sebagai bentuk penghargaan diri sendiri, "I deserve it";

7. Untuk menghukum pihak lain, "they deserve it". ${ }^{14}$

Selain berujung pada bertambah burukn ya konflik, eskalasi dalam konflik juga dapat berujung kepada negosiasi. Situasi yang memungkinkan terjadinya negosiasi tersebut dapat diinisiasi oleh aktor yang terlibat maupun oleh pihak ketiga. ${ }^{15}$ Layaknya eskalasi, negosiasi juga memiliki struktur langkah yang responsif. Negosiasi merupakan sebuah pertukaran penawaran dari sudut pandang yang berbeda untuk mencapai kesepakatan bersama, di mana dalam prosesnya diatur oleh proses resiprokal y ang menyeluruh. ${ }^{16}$

Terdapat berbagai macam variabel yang dapat mempengaruhi eskalasi. Variabelvariabel tersebut muncul pada beberapa mekanisme berikut:

\section{Fear and fatigue}

\footnotetext{
${ }^{13}$ Idem., 8.

${ }^{14}$ Idem., 9.

15 Idem., 5.

16 Idem., 11.
}

2. Mutually hurting stalemates

3. Changes in stakes

4. Changes in parties

5. Changes in attitudes

6. Disengagement and breathing space

7. Confidence and security-building measures (CSBMs)

8. Learning processes

9. Reaffirmed relationship

10. Mutually enticing opportunity (MEO)

11. Cultural values. ${ }^{17}$

Mekanisme-mekanisme di atas dapat menggiring situasi konflik dari eskalasi menuju negosiasi. Setelah terdapat mekanisme yang menciptakan situasi negosiasi, rute komunikasi pun terbuka dan nego siasi dapat dimulai.

\section{Negosiasi Pembebasan Sandera}

Penyanderaan seringkali ditujukan untuk menciptakan situasi kekuasaan. Menjadi hal yang wajar apabila penyanderaan menjadi semacam senjata bagi yang lemah untuk menyerang dan mendiskreditkan negara dan pemerintah sebagai pihak otoritas yang berwenang. Dalam rangka membebasakan sandera, diperlukan pemahaman akan motif dan tujuan dari teroris yang melakukan penyanderaan. Terorisme dapat dibedakan menjadi 3 kategori, kelompok terorisme politik, kelompok terorisme religius, dan kelompok terorisme ekonomi. ${ }^{18}$

Margaret Wilson menyatakan bahwa bentuk penyanderaan kidnapping merupak an bentuk penyanderaan yang paling sulit diintervensi oleh pihak berwenang. ${ }^{19} \mathrm{Hal}$ ini disebabkan sifat kidnapping yang mobile di mana sandera dapat dipindahkan dari satu lokasi ke lokasi lainnya. Untuk mengatasi persoalan kidnapping, terdapat beberapa prosedur yang tersedia untuk membebaskan

\footnotetext{
${ }^{17}$ Idem., 12-13.

18 Faure, G. 2011. Negotiating with Political, Ideological, and Criminal Terrorist. Jornadas secuestros y toma de rehenes por parte de grupos terroristas prevención y respuestas : 4 .

${ }^{19}$ Ibid.
} 
sandera. Federal Bureau Investigation (FBI), mendasari pembebasan sandera dengan keterampilan active-listening. ${ }^{20}$ Dengan keterampilan active-listening, empati negosiator dapat ditunjukkan kepada penyandera. Dasar dari keterampilan activelistening adalah basic listening sequence (BLS). BLS terdiri dari pertanyaan bersifat open-ended, encouragers, dan refleksi, y ang kemudian BLS bertujuan untuk menunjukkan bahwa pendengar memahami (understand) penyandera. ${ }^{21}$ Dengan ditunjukkannya bahwa negosiator memahami penyandera, maka empati pun dapat muncul.

Apabila empati negosiator kepada penyandera berhasil ditunjukkan, maka langkah berikutnya adalah rapport atau hubungan baik antara negosiator dan penyandera, yang kemudian mampu mempengaruhi pemikiran dan perilaku penyandera. $^{22}$

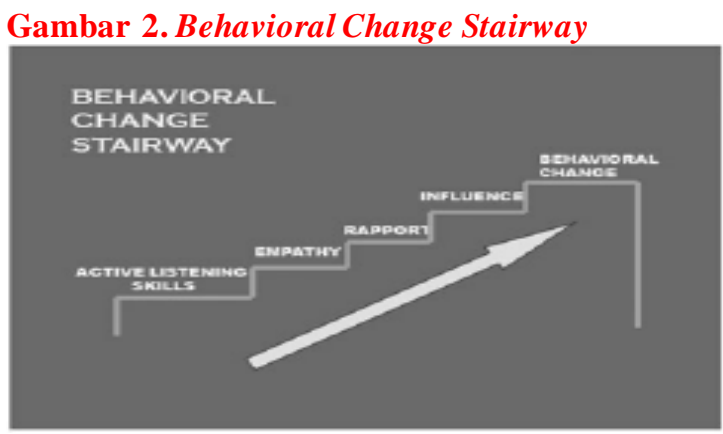

Sumber: McCains, M \& Mullins, W., 2015: 163

\section{METODE RISET}

Penelitian ini menggunakan teknik pengumpulan data melalui wawancara dan didukung oleh studi literatur. Teknik wawancara dipilih oleh penelitian karena akan membantu peneliti untuk mendapatkan data yang eksklusif dan tidak dapat diperoleh melalui sumber lain. Wawancara kualitatif dapat dilakukan dengan tatap muka, melalui

${ }^{20}$ McCains, M \& Mullins, W. Crisis Negotiations: Managing Critical Incidents and Hostage Situations in Law Enforcement and Corrections, New York: Routledge, 163.

${ }^{21}$ Ibid.

22 Ibid. telepon atau korespondensi, serta dalam bentuk wawancara kelompok dengan enam hingga delapan peserta di dalam kelompok. ${ }^{23}$ Wawancara kualitatif melibatkan pertanya an pertanyaan terbuka (open-ended) yang bertujuan untuk mendapatkan pandangan dan opini dari peserta. ${ }^{24}$

Proses penelitian kualitatif juga dapat ditunjang melalui pengumpulan dokumen kualitatif. Dokumen ini termasuk dokumen publik seperti koran, notulensi rapat, laporan resmi atau dokumen privat seperti jurnal pribadi, surat, dan surat elektronik. ${ }^{25}$ Strate gi analisis data merupakan tahapan selanju tnya setelah pengumpulan data, dimana penelitian melakukan proses analisa dari data tersebut. Terdapat lima tahapan strategi analisis data menurut Creswell, yaitu:

1. Pengumpulan data;

2. Membaca keseluruhan data;

3. Mendeskripsikan data;

4. Penyajian data;

5. Penarikan kesimpulan dan intepretasi data. $^{26}$

Pengumpulan data dilakukan melalui teknik wawancara, studi pustaka, dan internet-based research. Data kemudian dideskripsikan dengan konsep serta teori yang ada. Data yang telah dideskripsikan kemudian disajikan, disimpulkan, dan diinterpretasi oleh peneliti.

\section{HASIL DAN PEMBAHASAN}

Profil Aktor yang Terlibat dalam Pembebasan Sepuluh Sandera Warga Negara Indonesia

Salah satu variabel dari negosiasi konflik adalah sifat dan penyebab dari terjadinya konflik. Sif at dan penyebab konflik kemudian dapat menentukan eskalasi, de-eskalasi, serta negosiasi yang dapat terjadi dalam sebuah konflik. Untuk memahami sifat dan penyebab konflik, diperlukan pemahaman akan karak ter dari pihak-pihak yang terlibat dalam konflik. Berkaitan dengan peristiwa pembebasan

\footnotetext{
${ }^{23}$ Idem., 230-232

${ }^{24}$ Ibid.

${ }^{25}$ Ibid

26 Idem., 237-245
} 
sandera 10 WNI yang menjadi ABK di kapal tunda Brahma 12 dan kapal ton gkang An and 12, maka pihak-pihak yang terlibat diantaranya adalah Kelompok Abu Sayyaf, Yayasan Sukma, Indonesia, serta Filipina.

\section{Profil Kelompok Abu Sayyaf}

Untuk memahami motif dan tujuan dari Kelompok Abu Sayyaf dalam menyandera 10 WNI, tentu perlu dipahami profil Kelompok Abu Sayyaf secara mendalam. Secara etimologi nama "Abu Sayyaf" memiliki arti pembawa pedang. Nama "Abu Sayyaf" juga dapat memiliki arti ayah dari pedang. Jejak sejarah berdirinya Kelompok Abu Sayyaf memiliki kaitan yang erat dengan pendirinya, Abdurajak Abubakar Janjalani. Abdurajak Janjalani adalah seorang anak tokoh agama di Basilan. Abdurajak Janjalani sempat mengenyam pendidikan di Arab Saudi, dan kembali ke Filipina pada tahun 1984.

Di tahun 1987, Abdurajak Janjalani melakukan perjalanan ke Libya. Selama perjalanannya, Abdurajak Janjalani kemu dian turut mengikuti kamp latihan di Afghanistan bersama ratusan militan Moro lainnya untuk bertempur dengan Mujahidin Afghanistan melawan invasi Uni Soviet. Selama menjalan i pelatihan militer di Afghanistan, Abdurajak Janjalani dikomandoi oleh Abdur Rab Rasul Sayyaf, seorang panglima militer dari faksi Ittihâa al-Islâmî. Dengan terinspirasinya Abdurajak Janjalani terhadap Panglima Abdur Rab Rasul Sayyaf, nama Abu Sayyaf pun dipergunakan oleh Abdurajak Janjalani sebagai nama alias. Abdurajak Janjalani diperkirakan merupakan anggota dari jajaran Executive Council of the Islamic International Brigade, yang selanjutnya akan membentuk jaringan internasional Al-Qaeda. ${ }^{27}$ Pada tahun 1989, Abdurajak Janjalani kemudian melakukan perekrutan. Banyak dari anggota

27 Freeman Spogli Institute for International Studies. (6, August 2018). Stanford Center for International Security and Cooperation. Diambil 12 Maret 2020 dari Stanford University: https://cisac.fsi.stanford.edu/mappingmilitants/p rofiles/abu-sayyaf-group yang direkrut merupakan para an ggota Moro National Liberation Front (MNLF) yang merasa tidak puas terhadap kepemimpinan Nur Misuari. $^{28}$ Nur Misuari sendiri sempat membuka kesempatan untuk mengadakan dialog dengan pemerintah Filipina.

Setelah terkumpulnya anggota, Abdurajak Janjalani bersama para anggota pun membentuk Kelompok Abu Sayyaf. Meski telah ada kelompok bersenjata yang serupa Kelompok Abu Sayyaf, seperti MNLF dan Moro Islamic Liberation Front (MILF), Kelompok Abu Sayyaf muncul sebagai alternatif atas dua kelompok di atas. Kelompok Abu Sayyaf sendiri memiliki tujuan untuk mendirikan negara Islam Sunni Salafi yang independen di wilayah Mindanao. Tujuan tersebut terbentuk salah satunya oleh narasi sejarah dari perjuangan bangsa Moro menghadapi opresi oleh penjajahan bangsa Spanyol, Amerika, dan juga pemerintah Filipina. ${ }^{29}$ Leluhurbangsa Moro sendiri telah menduduki wilayah Mindanao sebelum abad ke-14. Selain itu Kelompok Abu Say yaf juga memiliki tujuan untuk mengusir para penduduk Nasrani yang telah bermigrasi ke wilayah Filipina Selatan sejak tahun 1910 setelah adanya dorongan dari pemerintah. ${ }^{30}$ Dalam melakukan perekrutan, Kelompok Abu Sayyaf juga memanfaatkan isu kesenjangan ekonomi antara masyarakat Moro dengan masyarakat Filipina pada umumnya. Dampaknya, banyak dari anggota Kelompok Abu Sayyaf merupakan kelompok masyarak at yang tidak memiliki akses ekonomi sama sekali. $^{31}$

Keberadaan Kelompok Abu Sayyaf kemudian dianggap Al-Qaeda dapat berperan sebagai perpanjangan tangan Al-Qaeda di Asia, khususnya Filipina. Osama bin Laden, yang sempat bertemu dengan Abdurajak Janjalani selama melakukan perjalanannya dulu, kemudian mengutus Muhammad Jamal

\footnotetext{
28 Ibid.

29 Ibid.

${ }^{30}$ Ibid.

${ }^{31}$ Ibid.
} 
Khalifa untuk memberikan pendampingan serta pendaan kepada Kelompok Abu Sayyaf..$^{32}$ Osama bin Laden juga memberikan pelatihan perakitan bom kepada para anggo ta Kelompok Abu Sayyaf melalui Ramzi Yousef.

Dengan adanya bantuan pendanaan oleh Osama bin Laden, Kelompok Abu Sayyaf pun dapat mempersenjatai para anggotanya. Hal ini berdampak pada semakin dikenalnya Kelompok Abu Sayyaf oleh masyarakat luas . Namun hubungan Al-Qaeda dengan Kelompok Abu Sayyaf tak selamanya mulus. Komunikasi keduanya terganggu dengan diblokirnya Muhammad Jamal Khalifa oleh pemerintah Filipina.

Situasi semakin buruk bagi Kelompok Abu Sayyaf ketika sang pemimpin, Abdurajak Janjalani, tewas setelah melakukan kontak senjata api dengan pasukan bersenjata Filipina 18 Desember 1998. Pasca kematian Abdurajak Janjalani, Kelompok Abu Sayyaf kemudian terpecah menjadi dua faksi utama, faksi Basilan yang dipimpin oleh Khadaffy Janjalani dan faksi Sulu yang dipimpin oleh Galib Andang yang juga dikenal sebagai Commander Robot. ${ }^{33}$ Dengan terputusnya bantuan dari Al-Qaeda serta absennya figur karismatik seperti Abdurajak Janjalani, menyebabkan terganggunya kedisiplinan dari anggota Kelompok Abu Sayyaf.

Dihadapkan dengan permasalahan ini, Kelompok Abu Sayyaf yang sebelumnya melakukan aktivitas terorisme seperti pemboman dan penembakan dengan tujuan memerdekakan bangsa Moro dari Filipina, beralih modus operandi menjadi penyanderaan dengan tujuan mendapatkan uang tebusan (kidnapping-for-ransom). Beralihnya motif atau tujuan dari aktivitas Kelompok Abu Sayyaf tersebut terlihat dengan jumlah korban

32 Fellman, Z. (n.d.). Homeland Security \& Counterterorrism Program Transnational Threats Project. Diambil 12 Maret 2020 dari Center for Strategic \& International Studies: https://csis-prod.s3.amazonaws.com/s3fspublic/legacy_files/files/publication/111128_Fe llman_ASG_AQAMCa seStudy5.pdf ${ }^{33}$ Ibid. penyanderaan yang dibunuh kelompok ini dalam tahun 2000 dan 2001, yakni 16 jiwa.

Selanjutnya pada tahun 2002 pemerintah Filipina berhasil membekuk Abu Sabaya dan Commander Robot, dua rival Khadaffy Janjalani di tubuh internal Kelompok Abu Sayyaf. Hal ini justru menyebabkan tersentralisasinya Kelompok Abu Sayyaf di bawah kepemimpinan Khadaffy Janjalani. Di bawah kepemimpinan Khadaffy Janjalani yang tersentralisasi tersebut, Kelompok Abu Sayyaf kembali fokus kepada cita-cita para pendirinya yakni untuk mendirikan negara Islam di Filipina Selatan.

Namun Kelompok Abu Sayyaf kembali mengalami perpecahan setelah terbunuhnya Khadaffy Janjalani di akhir tahun 2006. Terbunuhnya Abu Sulaiman, yang selama ini turut membentuk aliansi antara Kelompok Abu Sayyaf dan Jemaah Islamiyah, semakin membuat kelompok ini timpang. Kedua peristiwa tersebut menyebabkan kembaliny a para anggota Kelompok Abu Sayyaf untuk melakukan kidnapping-for-ransom. Di tah un 2010 Kelompok Abu Sayyaf bahkan berhasil memperoleh uang tebusan senilai US\$ 704 ribu setelah melakukan penyanderaan terhadap 10 orang. ${ }^{34}$

Dengan bertransformasinya Kelompok Abu Sayyaf menjadi organisasi yang beroperasi dengan skala kecil dan fokus pada kidnappingfor-money, banyak dari ahli tidak lagi memandang Kelompok Abu Sayyaf sebagai sebuah kelompok yang memperjuangkan tercapainya suatu ideologi ataupun sebagai organisasi teroris, melainkan sebagai kelompok kriminal. Hal tersebut juga sesuai dengan pernyataan narasumber yang menyatakan bahwa saat ini Kelompok Abu Sayyaf melakukan tindakan kriminal hanya untuk keuntungan ekonomi semata.

Tentu dengan ketidakjelasan status Kelompok Abu Sayyaf turut mempersulit pihak negosiator yang hendak membebaskan sandera. Hingga tahun 2020, Kelompok Abu Sayyaf juga masih kerap melakukan

\footnotetext{
34 Ibid.
} 
penyanderaan (kidnapping-for-money), meski berbagai upaya telah dilakukan baik oleh pihak non-formal maupun pihak pemerintah Filipina. ${ }^{35}$ Saat ini Kelompok Abu Sayyaf berada di bawah pimpinan beberapa figur, yakni Yasser Igasan alias Kumander Diang, Radulan Sahiron alias Commander Putol, d an Isnilon Totoni Hapilon alias Abu Musab. ${ }^{36}$

\section{Profil Yayasan Sukma}

Cikal bakal berdirinya Yayasan Sukma adalah terjadinya bencana tsunami di Aceh pada tahun 2004. Selepas terjadinya bencana tsunami di Aceh tersebut, Media Group kemudian melakukan aktivitas kemanusiaan di bawah program "Indonesia Menangis". Aktivitas kemanusiaan "Indonesia Menan gis" tersebut melibatkan partisipasi berbagai pihak individu maupun institusi dari dalam dan luar negeri. Aktivitas kemanusiaan yang diorganisir oleh Media Group ini terbagi ke dalam dua fase.

Pada fase pertama aktivitas yang dilakukan merupakan respon darurat, yang di an taranya berbentuk penyaluran berbagai kebutuhan pokok seperti makanan, pakaian, obat-obatan, alat medis, dan berbagai peralatan evakuasi. Pada fase ini mobilisasi tenaga relawan serta pembentukan pos untuk mencari korban hilang juga dilakukan. Fase pertama dimulai pada tanggal 27 Desember 2004 dan berakhir pada 28 Februari 2005. ${ }^{37}$ Sedangkan pada fase kedua aktivitas yang dilakukan merupakan rehabilitasi sektor pendidikan. Pembangunan sekolah di wilayah bencana serta bantuan

35 Yahya, A. N. (2020, March 3). Kompas.com. Diambil March 18, 2020, from Kompas.com: https://na sional.kompas.com/read/2020/03/03/2 0325651/abu-sayyaf-minta-tebusan-beb askan5-wni-mahfud-segera-lakukan-pembahasan

36 Freeman Spogli Institute for International Studies. (6, August 2018). Stanford Center for International Security and Cooperation. Diambil March 12, 2020, from Stanford University: https://cisac.fsi.stanford.edu/mappingmilitants/p rofiles/abu-sayyaf-group

37 Yayasan Sukma. (2018). About Us. Diambil April 13, 2020, from Yayasan Sukma: https://yayasan-sukma.org/about-us kepada sektor kesehatan dilakukan pada fase ini. Sektor pendidikan dianggap sebagai isu dan prioritas utama dalam fase kedua. Sebab, sebagai dampak bencana tsunami di mana banyak diantara korbannnya adalah tenaga pengajar, Aceh diperkirakan kehilangan potensi intelektual hingga $35 \% .{ }^{38}$ Selain itu banyak fasilitas pendidikan yang men galami kerusakan.

Berdasarkan prioritas pada fase kedua tersebut, serta untuk memudahkan tata kelola dana donasi dalam jangka panjang secara profesional, maka Chairman dari Media Group kemudian memutuskan untuk membentuk Yayasan Sukma. Yayasan Sukma didirikan di Jakarta melalui surat notaris nomor 15 pada tanggal 25 February 2005. ${ }^{39}$ Sehingga, semenjak didirikannya Yayasan Sukma fokus kepada aktivitas kemanusiaan, terutama pendidikan. Melalui Yayasan Sukma, para anak korban bencana pun mendapatkan berbagai fasilitas pendidikan, seperti asrama dan tenaga pengajar yang didatangkan dari berbagai tempat. Para siswa yang dibantu oleh Yayasan Sukma juga berprestasi dengan mengikuti kompetisi seni budaya di Tiongkok.

Yayasan Sukma juga terlibat dalam pembebasan sandera Kelompok Abu Sayyaf dengan mengirimkan tim negosiator yang beranggotakan Mayor Jenderal Purnawira wan Supriadin, Ahmad Baedowi, Samsu Rizal Panggabean, serta Desi Fitriani. ${ }^{40}$ Mayor Jenderal Purnawirawan Supriadin merupakan mantan Panglima Komando Daerah Militer Iskandar Muda Aceh. Kemudian, Ahmad Baedowi merupakan Direktur Pendidikan Sukma. Selanjutnya, Samsu Rizal Panggabean merupakan pengajar di jurusan Hubungan Internasional serta Magister Perdamaian dan Resolusi Konflik Universitas Gajah Mada. Sedangkan Desi Fitriani merupakan jurnalis Metro TV. Setidaknya terdapat 30 anak

${ }^{38}$ Ibid

39 Ibid.

40 Dewi, P. R. (2019). The Use of Multitrack Diplomacy in The Liberation Of 10 Indonesian Ship Crew From The Abu Sayyaf Group 2016. Andalas Journal of International Studies, 200. 
Mindanao yang bersekolah di Yayasan Sukma sebagai dampak dari keterlibatan Yayasan Sukma pada pembebasan sandera Warga Negara Indonesia oleh Kelompok Abu Sayy af di Filipina Selatan tersebut. Berdasarkan wawancara penelitian dengan seorang atase Konsulat Jenderal Republik Indonesia di Davao, diketahui bahwa pasca peristiwa terbebasnya 10 sandera WNI pada 1 Mei 2016, Yayasan Sukma memang bekerja sama dengan Atase Kebudayaan KBRI Manila untuk selanjutnya dapat memberikan beasiswa kepada anak-anak yang berada di Filipina Selatan.

\section{Negosiasi Pembebasan Sandera}

Setelah mendapatkan kabar disanderanya 10 WNI oleh Kelompok Abu Sayyaf, Indonesia pun menanggapinya dengan cepat dan terbuka. Mengingat penyanderaan terjadi di teritori Filipina, maka Indonesia memutuskan untuk tidak melibatkan angkatan bersenjata dan mengandalkan keterlibatan aktor non-negara. Dengan melibatkan aktor non-negara, Indonesia berharap pembebasan sandera dapat dilakukan dengan lebih cepat karena tidak perlu melewati prosedur birokrasi. Yayasan Sukma kemudian mengirimkan tim negosiator yang selanjutnya menjadi salah satu aktor non-negara yang terlibat dalam pembebasan sandera 10 WNI yang menjadi ABK kapal tunda Brahma 12 dan kapal ton gkang An and 12.

Tim negosiator Yayasan Sukma diantaranya terdiri dari Mayor Jenderal Purnawirawan Supriadin, Ahmad Baedowi, Samsu Rizal Panggabean, serta Desi Fitriani. Pada awalnya, tim negosiator Yayasan Sukma hanya ditugaskan untuk melakuk an mapping dan assessment..$^{41}$ Namun seiring berjalanny a operasi, tim negosiator Yayasan Sukma kemudian berhasil mendapatkan akses un tuk melakukan komunikasi dengan anggota

41 Debora, Yantina, Adhi Bhaskara, Ign L, Indra, Putu Agung Nara. (2016). Terlalu Naif Kalau Tanpa Uang Tebusan. Diambil November 28, 2019, from tirto.id: https://tirto.id/terlalu-naifkalau-tanpa-uang-tebusan-bliy
Kelompok Abu Sayyaf. Akses tersebut berhasil didapat setelah tim negosiator Yayasan Sukma turut melibatkan komunitas lokal di Filipina untuk membebaskan sandera. Meski dengan melakukan kontak dengan Kelompok Abu Sayyaf merupakan hal yang berisiko, tim negosiator Yayasan Sukma memerlukan proof of life dari kesepuluh WNI yang disandera oleh Kelompok Abu Sayyaf.

Misi dari tim negosiator Yayasan Sukma pun meningkat menjadi negosiasi pembebasan sandera. Dalam rangka menghadapi Kelompok Abu Sayyaf, tim negosiator Yayasan Sukma menekankan pendekatan kemanu siaan. Pada saat kontak dengan Kelompok Abu Sayyaf dilakukan, tim negosiator Yayasan Sukma menyertakan unsur kebudayaan dan agama sebagai perwujudan pendekatan kemanu sia an tersebut. Unsur kebudayaan dan agama y ang disertakan antara lain adalah kue bakpia, keripik peyek, rokok, serta kitab suci AlQuran. ${ }^{42}$ Detil dari pendekatan kemanusiaan oleh tim negosiator Yayasan Sukma sendiri akan dibahas lebih lanjut pada bagian selanjutnya. Dengan pendekatan kemanusia an tersebut, tim negosiator Yayasan Sukma pun berhasil mendapatkan kepercayaan dari Kelompok Abu Sayyaf untuk melakukan negosiasi.

Pada 1 Mei 2016, kesepuluh sandera kemudian berhasil dibebaskan dengan uang tebusan 5 juta peso, dan kemudian diantarkan ke rumah Gubernur Sulu untuk selanjutnya diterbangkan ke Indonesia. ${ }^{43}$ Sebagai langk ah preventif, Yayasan Sukma kemudian menjalin kerja sama dengan Atase Kebudayaan Kedutaan Besar Republik Indonesia di Manila. Sejumlah anak-anak di Filipina Selatan juga diberikan beasiswa pendidikan oleh Yayas an Sukma.

\footnotetext{
42 Ibid.

43 Ibid.
} 
Aktor yang Terlibat dalam Pembebasan Sepuluh Sandera Anak Buah Kapal Warga Negara Indonesia

Untuk membebaskan 10 WNI ABK kapal tunda Brahma 12 dan kapal tongkang An and 12 menjadi hal yang rumit bagi Indonesia mengingat kesepuluh WNI disandera oleh kelompok kriminal diluar wilayah kedau latan Indonesia. Dengan kondisi tersebut, Indonesia tidak dapat menggunakan kekuatan militern ya mengingat apabila Indonesia menggunakan kekuatan militer, Filipina sebagai negara di mana tempat penyanderaan terjadi, akan melihatnya sebagai sebuah agresi Indonesia terhadap kedaulatan Filipina.

Oleh karenanya Indonesia kemudian melibatkan aktor-aktor non-negara yang dap at terjun langsung ke Filipina untuk dapat membebaskan kesepuluh WNI yang disandera. Pelibatan aktor non-negara tersebut dapat dijelaskan dengan konsep multi-track diplomacy. Dalam upaya membebaskan sandera $10 \mathrm{ABK}$ WNI kapal tunda Brahma 12 dan kapal tongkang Anand 12 Indonesia kemudian melibatkan dua kelompok negosiator yang masing-masing dibentuk oleh Yayasan Sukma dan Jusuf Kalla. Kelo mpok negosiator Yayasan Sukma terdiri dari Mayor Jenderal Purnawirawan Supriadin, Ahmad Baedowi, Samsu Rizal Panggabean, serta Desi Fitriani. ${ }^{44}$ Mayor Jenderal Purnawirawan Supriadin merupakan mantan Panglima Komando Daerah Militer Iskandar Muda Aceh, Ahmad Baedowi merupakan Direktur Pendidikan Sukma, Samsu Rizal Pan ggabean merupakan pengajar di jurusan Hubungan Internasional serta Magister Perdamaian dan Resolusi Konflik Universitas Gajah Mada, sedangkan Desi Fitriani merupakan jurnalis Metro TV.

Dalam operasinya, kelompok negosiator Yayasan Sukma melibatkan masyarakat lokal Mindanao dan melakukan koordinasi secara

44 Dewi, P. R. (2019). The Use of Multitrack Diplomacy in The Liberation Of 10 Indonesian Ship Crew From The Abu Sayyaf Group 2016. Andalas Journal of International Studies, 200. berkala dengan pihak pemerintah melalui Eddy Mulya sebagai Konselor Menteri Kedutaan Besar Republik Indonesia di Filipina. Pelibatan aktor non-pemerintah oleh Indonesia dalam membebaskan 10 sandera WNI tersebut dapat dilihat menggunakan kacamata multi-track diplomacy. Pada track satu multi-track diplomacy, yang aktornya adalah pemerintah, Indonesia berupaya melalui Kemenlu serta KBRI Manila dan jajarannya, TNI, pemerintah Filipina beserta kepolisian Filipina dan angkatan bersenjata Filipina. Kelompok yang dibentuk oleh Ju suf Kalla yang beranggotakan Hamid Awaludin, tokoh Palang Merah Indonesia, dapat dikategorikan sebagai track empat multi-track diplomacy.

Dalam hal ini, Hamid Awaludin menggunakan relasinya dengan pihak Palang Merah di Filipina untuk mengumpulkan informasi mengenai 10 WNI yang menjadi sandera Kelompok Abu Sayyaf. Sedangkan, kelompok yang dikirim oleh Yayasan Sukma, dapat dikategorikan ke dalam track dua, track lima, track enam, serta track tujuh dalam multi-track diplomacy. Luasnya cakupan kelompok negosiator yang dibentuk oleh Yayasan Sukma disebabkan oleh beraga mnya latar belakang dari anggota kelompok negosiator. Rizal Samsu Panggabean, sebagai pengajar di jurusan Hubungan Internasional serta Magister Perdamaian dan Resolusi Konflik Universitas Gajah Mada, merupakan anggota kelompok negosiator Yayasan Sukma yang masuk ke dalam track dua. Aktor dari track dua merupakan ahli konflik resolusi. Selanjutnya, Ahmad Baedowi sebagai Direktur Pendidikan Yayasan Sukma, merupakan perwujudan dari track lima, di mana aktornya adalah institusi pendidikan.

Sedangkan perwujudan dari track enam dan track tujuh oleh tim negosiator yang diben tuk oleh Yayasan Sukma adalah aktivitas tim Yayasan Sukma guna membebaskan 10 sandera WNI yang menggunakan pendekatan kemanusiaan berupa budaya dan agama. 
Tabel 2. Aktor Multi-track Diplomacy

\begin{tabular}{|c|l|}
\hline Track & \multicolumn{1}{|c|}{ Aktor } \\
\hline 1 & $\begin{array}{l}\text { Pemerintah Indonesia, Kemenlu, } \\
\text { KBRI Manila, Pemerintah Filipina }\end{array}$ \\
\hline 2 & Tim Negosiator Yayasan Sukma \\
\hline 4 & Kelompok Jusuf Kalla \\
\hline 5 & Tim Negosiator Yayasan Sukma \\
\hline 6 & Tim Negosiator Yayasan Sukma \\
\hline 7 & Tim Negosiator Yayasan Sukma \\
\hline
\end{tabular}

Sifat dan Penyebab Penyanderaan Sepuluh Warga Negara Indonesia

Peristiwa penyanderaan 10 WNI ABK kapal tunda Brahma 12 dan kapal tongkang An and 12 dapat dipandang sebagai sebuah konflik. Zartmann menyatakan bahwa konflik terjadi ketika terdapat dua atau lebih pihak memiliki perbedaan pandangan dan berusaha memaksakan kehendak mereka. ${ }^{45}$ Dalam peristiwa penyanderaan $10 \mathrm{ABK}$ kapal tun da Brahma 12 dan kapal tongkang Anand 12, pihak yang terlibat dalam konflik pada awalnya adalah Indonesia dan Kelompok Abu Sayyaf. Indonesia memiliki perbedaan pandangan dengan Kelompok Abu Sayyaf.

Indonesia memandang 10 WNI ABK kapal tunda Brahma 12 dan kapal ton gkang An and 12 sebagai warga negara yang wajib dilindungi, sedangkan Kelompok Abu Say yaf memandang 10 WNI ABK kapal tunda Brahma 12 dan kapal tongkang Anand 12 sebagai alat untuk membantu keuangan organisasi.

Dalam peristiwa penyanderaan $10 \mathrm{ABK}$ WNI, sifat dan penyebab dari terjadinya konflik antara Kelompok Abu Sayyaf den gan Indonesia adalah keinginan Kelompok Abu Sayyaf untuk mendapatkan uang tebusan. Uang tebusan diperlukan oleh Kelompok Abu Sayyaf untuk menopang kebutuhan operasi Kelompok Abu Sayyaf. Selain itu, uang tebusan juga digunakan untuk kesejahteraan para anggota kelompok. Oleh karenanya, Kelompok Abu Sayyaf seringkali melakukan

45 Zartmann, I. \& Faure, G. 2005. Escalation and Negotiation in International Conflicts. New York: Cambridge University Press, 4 penyanderaan. Namun apabila ditelisik lebih dalam, uang tebusan bukanlah penyebab utama dari dilakukannya penyanderaan oleh Kelompok Abu Sayyaf serta terjadinya konflik antara Kelompok Abu Sayyaf dengan Indonesia.

Kelompok Abu Sayyaf, juga kelompokkelompok bersenjata di Filipina Selatan lainnya, melakukan operasinya dengan dasar adanya pandangan penduduk Filipina Selatan yang merasa dimarjinalkan oleh pemerintah Filipina. Hal ini terlihat dari kondisi sosial ekonomi masyarakat Moro di Filipina Selatan. Selain itu, perbedaan latar belakang seperti budaya dan agama semakin memperkuat semangat Kelompok Abu Sayyaf untuk melakukan berbagai tindakan kejahatan. Sehingga dapat disimpulkan uang tebusan adalah penyebab terjadinya konflik, meski penyebab utamanya bukanlah semata-mata masalah ekonomi. Kelompok Abu Sayyaf memandang keputusan untuk menyandera 10 WNI ABK kapal tunda Brahma 12 dan kapal tongkang Anand 12 dengan tujuan untuk memanfaatkan momen untuk mendapatkan keuntungan - dalam hal ini uang tebusan - di kemudian hari. Pemanfaatan momen (seize an advantage) ini juga bertujuan untuk menutupi kebutuhan biaya operasi Kelompok Abu Sayyaf di masa lalu.

Tabel 2. Sifat dan Penyebab Aktor Melakukan Konflik

\begin{tabular}{|l|l|l|}
\hline No. & Aktor & $\begin{array}{l}\text { Sifat dan Penyebab } \\
\text { Konflik }\end{array}$ \\
\hline 1. & $\begin{array}{l}\text { Kelompok } \\
\text { Abu Sayyaf }\end{array}$ & $\begin{array}{l}\text { Perbedaan identitas dan } \\
\text { sosio-kultural Filipina } \\
\text { masyarakat dengan } \\
\text { Selatan } \\
\text { masyarakat Filipina }\end{array}$ \\
\hline 2. & $\begin{array}{l}\text { Kelompok } \\
\text { Abu Sayyaf }\end{array}$ & $\begin{array}{l}\text { Tindakan } \\
\text { pemberontakan terhadap } \\
\text { pemerintah Filipina }\end{array}$ \\
\hline 3. & $\begin{array}{l}\text { Kelompok } \\
\text { Abu Sayyaf }\end{array}$ & $\begin{array}{l}\text { Mendapatkan } \\
\text { keuntungan ekonomi } \\
\text { (uang tebusan) }\end{array}$ \\
\hline 4. & Indonesia & $\begin{array}{l}\text { Melindungi Warga } \\
\text { Negara Indonesia }\end{array}$ \\
\hline
\end{tabular}


Eskalasi Penyanderaan Sepuluh Warga Negara Indonesia

Keputusan Kelompok Abu Sayyaf untuk melakukan penyanderaan terhadap $10 \mathrm{WNI}$ ABK kapal tunda Brahma 12 dan kapal tongkang Anand 12 dapat dipandang sebagai sebuah bentuk eskalasi. Konflik sendiri memiliki struktur yang terbentuk atas eskalasi. ${ }^{46}$ Eskalasi dapat diartikan sebagai sebuah peningkatan dalam konflik, sebuah langkah taktis yang berdampak pada sifat konflik itu sendiri. Sedangkan dalam peristiwa penyanderaan sendiri, konflik telah bermula ketika adanya perbedaan pandangan antara Indonesia dengan Kelompok Abu Sayyaf ata s $10 \mathrm{WNI}$.

Eskalasi dalam konflik dapat berujung pada kesempatan untuk bernegosiasi dalam situasi tertentu ${ }^{47}$ Eskalasi dapat terjadi pada berbagai dimensi dalam konflik. Dalam peristiwa penyanderaan 10 WNI ABK kapal tunda Brahma 12 dan kapal tongkang Anand 12, Kelompok Abu Sayyaf melakukan escalation of means, yakni diberikannya tuntutan (demand) berupa uang dan sebagai gantinya memberikan penawaran (offers) berupa dibebaskannya sandera 10 WNI ABK.

Menanggapi adanya permasalahan ini, pihak lawan Kelompok Abu Sayyaf, yang dalam peristiwa penyanderaan $10 \mathrm{WNI}$ tersebut adalah Indonesia, kemudian memutuskan untuk melibatkan aktor nonformal untuk melakukan pembebasan sandera. Keputusan Indonesia untuk melibatkan pihak lain dalam konsep eskalasi konflik merupakan sebuah escalation of parties. Aktor non-formal seperti tim negosiator yang dibentuk oleh Yayasan Sukma pun, sebagai dampak dari escalation of parties, kemudian turut menjadi salah satu pihak (party) dalam peristiwa penyanderaan $10 \mathrm{WNI}$ ABK.

Strategi yang dilancarkan oleh tim negosiator Yayasan Sukma guna membebaskan sandera adalah pendekatan kemanusiaan melalui pendekatan budaya, agama, dan pendidikan. Tim negosiator Yayasan Sukma dalam operasinya juga menjalin hubungan dengan komunitas masyarakat di Filipina. Tujuan tim negosiator Yayasan Sukma menjalin hubungan dengan komunitas lokal Filipina diantaranya adalah untuk melakukan assessment dan mapping Kelompok Abu Sayyaf.

Setelah menjalin hubungan dengan komunitas lokal Filipina, tim negosiator Yayasan Sukma kemudian mendapatkan akses untuk melakukan kontak dengan Kelompok Abu Sayyaf. Melakukan kontak secara langsung dengan Kelompok Abu Sayyaf merupakan hal yang penting mengingat tim negosiator Yayasan Sukma butuh proof of life dari 10 sandera WNI. Namun, melakukan kontak langsung dengan Kelompok $\mathrm{Abu}$ Sayyaf juga menjadi hal yang berbahaya.

Dengan dilakukannya kontak langsung oleh tim negosiator Yayasan Sukma, tim negosiator Yayasan Sukma secara tidak langsung telah melakukan escalation of risk.

Tabel 3. Eskalasi Konflik oleh Aktor

\begin{tabular}{|l|ll|l|}
\hline No. & $\begin{array}{l}\text { Eskalasi } \\
\text { Konflik }\end{array}$ & $\begin{array}{l}\text { Peristiwa } \\
\text { means }\end{array}$ & $\begin{array}{l}\text { Escalation of means } \\
\text { terjadi ketika } \\
\text { Kelompok Abu } \\
\text { Sayyaf memberikan } \\
\text { offer dan demand } \\
\text { kepada Indonesia }\end{array}$ \\
\hline 2. & $\begin{array}{l}\text { Escalation of } \\
\text { parties }\end{array}$ & $\begin{array}{l}\text { Terjadi ketika } \\
\text { Indonesia } \\
\text { memutuskan untuk } \\
\text { melibatkan aktor } \\
\text { non-negara, } \\
\text { diantaranya Yayasan } \\
\text { Sukma }\end{array}$ \\
\hline 3. & $\begin{array}{l}\text { Escalation of } \\
\text { risk }\end{array}$ & $\begin{array}{l}\text { Terjadi ketika tim } \\
\text { negosiator Yayasan } \\
\text { Sukma melakukan } \\
\text { kontak langsung } \\
\text { dengan Kelompok } \\
\text { Abu Sayyaf }\end{array}$ \\
\hline
\end{tabular}

${ }^{46}$ Ibid, 6.

${ }^{47}$ Ibid, 5. 
De-eskalasi dan Negosiasi Sepuluh Sandera Warga Negara Indonesia

Dalam peristiwa pembebasan sepuluh sandera WNI, salah satu variabel de-eskalasi terjadi, changes in parties, setelah Indonesia memutuskan untuk melibatkan aktor nonnegara dalam membebaskan sandera. Changes in parties sendiri merupakan situasi dimana eskalasi konflik berubah menjadi situasi negosiasi, yang disebabkan oleh perubahan struktur internal pihak yang terlibat dalam konflik, atau terdapat pihak baru, atau terdapat eliminasi dari pihak yang sudah ada. ${ }^{48}$ Dengan adanya changes in parties, struktur decision making tidak sepenuhnya berada di tangan Indonesia. Variabel de-eskalasi berikutnya terjadi ketika tim negosiator Yaya san Suk ma melakukan kontak dengan Kelompok Yayasan Sukma.

Langkah tim negosiator Yayasan Sukma untuk melakukan kontak dengan Kelompok Abu Sayyaf merupakan langkah y ang cukup berisiko. Namun dengan melibatkan komunitas lokal di Filipina Selatan, tim negosiator Yayasan Sukma berhasil mendapatkan akses serta kepercay aan untuk melakukan kontak langsung dengan Kelompok Abu Sayyaf sekaligus mendapatkan proof of life 10 sandera WNI. Setelah tim negosiator Yayasan Sukma berhasil melakukan kontak dengan Kelompok Abu Sayyaf, komunikasi baik pun berusaha dibangun. Salah satu kunci keberhasilan terbentuknya komunikasi baik antara tim negosiator Yayasan Sukma dengan Kelompok Abu Sayyaf adalah digu nakanny a pendekatan kemanusiaan oleh tim ne gosiator Yayasan Sukma.

Menurut salah satu anggota tim negosiator Yayasan Sukma, Rizal Samsu Panggabean, tim negosiator Yayasan Sukma memandang para anggota Kelompok Abu Say yaf sebagai teman dan manusia yang dapat diajak berbicara. ${ }^{49}$ Dengan demikian active listening

\footnotetext{
${ }^{48}$ Idem., 12-13.

49 Debora, Yantina, Adhi Bhaskara, Ign L, Indra, Putu Agung Nara. (2016). Terlalu Naif Kalau Tanpa Uang Tebusan. Diambil November 28,
}

pun terjadi, dan tim negosiator Yayasan Sukma dapat mengetahui kebutuhan para anggota Kelompok Abu Sayyaf agar negosiasi dapat terus berjalan. Tim negosiator Yay as an Sukma juga turut memberikan berbagai suguhan kepada Kelompok Abu Sayyaf ketika akan melakukan negosiasi. Beberapa suguhan seperti Al Quran, kue bakpia, kripik, dan rokok pun diterima dengan baik oleh para anggkota Kelompok Abu Sayyaf. Dengan digunakannya unsur budaya d an agama oleh tim negosiator Yayasan Sukma, variabel cultural values dari de-eskalasi konflik pun terpenuhi.

Selain itu, dengan adanya komunikasi baik serta suguhan dengan unsur agama dan budaya tersebut, empathy pun terjadi. Ketika active listening dan empathy berhasil dilakukan, maka rapport dapat terwujud. Hal ini terlih at ketika Kelompok Abu Say yaf menunjukkan trust dengan memperlakukan tim negosiator dengan baik dan tanpa kekerasan. Bahkan para anggota Kelompok Abu Sayyaf turut memandang tim negosiator Yayasan Sukma sebagai teman (brothers). ${ }^{50}$ Maka terjadilah confidence and security building measure, $\mathrm{di}$ mana transparansi diantara kedua pihak berhasil terwujud dan ketakutan kedua pihak berhasil diredam. Agar komunitas lokal ikut serta untuk terlibat membebaskan 10 sandera WNI, tim negosiator Yayasan Sukma pun memberikan beasiswa pendidikan kepada anak-anak di Filipina Selatan. Setelah melakukan negosiasi dengan Yayasan Sukma, sandera pun berhasil dibebaskan dengan uang tebusan lima juta peso, setelah sebelumnya uang tebusan yang dituntut adalah sebesar lima puluh juta peso. ${ }^{51} 52$

2019, from tirto.id: https://tirto.id/terlalu-naifkalau-tanpa-uang-tebusan-bliy

${ }^{50}$ Ibid.

51 Ibid.

52 Prasetyo, Wisnu. (2016). Tentang Uang Tebusan 50 Juta Peso untuk 10 WNI dan Jalur Pelayaran RI-Filipina. Diambil 28 Januari 2020, dari detik.com: https://news.detik.com/berita/d3201861/tentang-uang-tebusan-50-juta-pesountuk-10-wni-dan-jalur-pelayaran-ri-filipina 
Perubahan jumlah uang tebusan tersebut merupakan indikasi bahwa variabel changes in attitudes telah terpenuhi. Zartmann mendefinisikan changes in attitudes sebagai sebuah titik dimana eskalasi konflik berh enti sebagai akibat ditunjukkannya kesediaan untuk bernegosiasi oleh salah satu pihak dalam konflik. ${ }^{53}$ Perubahan jumlah uang tebusan tersebut menjadi bukti bahwa tim negosiator telah berhasil melakukan negosiasi dengan Kelompok Abu Sayyaf. Perubahan jumlah uang tebusan tersebut juga menandakan bahwa influence dan behavioral change telah berhasil dilakukan oleh tim negosiator Yayasan Sukma. Keberhasilan negosiasi ditandai dengan dibebaskannya sepuluh sandera WNI oleh Kelompok Abu Sayyaf yang kemudian diantar ke rumah Gubernur Sulu, Abdusakaur Tan, sebelum akhirnya kesepuluh sandera dibawa ke rumah sakit di Barangay Busbus dan diterbangkan ke Indonesia. ${ }^{54}$ Keselamatan kesepuluh WNI yang disandera oleh Kelompok Abu Sayyaf tersebut merupakan hal yang luar biasa mengingat sulitnya melakukan komunikasi dengan Kelompok Abu Sayyaf. Kesulitan berkomunikasi tersebut seringkali menyebabkan terjadinya double payment atau bahkan triple payment atau bahkan terbunuhnya sandera. Dari sudut pandang pemerintah Indonesia, negosiasi pembebasan 10 sandera WNI masuk ke dalam kategori resort to a third party, di mana dalam peristiwa ini Indonesia melibatkan aktor nonnegara seperti Yayasan Sukma, yang selanjutnya juga melibatkan komunitaskomunitas lokal di Filipina.

Sedangkan dari sudut pandang tim negosiator Yayasan Sukma, negosiasi yang dilakukan untuk membebaskan 10 sandera WNI merupakan negosiasi dengan kategori step back from the action, di mana tim

53 Ibid., 12-13.

54 Wahono, Tri. (2016). Bebas dari Kelompok Abu Sayyaf, 10 WNI Sempat Dijamu Gubernur Sulu. Diambil January 28, 2020, from: https://internasional.kompas.com/read/2016/05/ 02/00483791/Bebas.dari.Kelompok.Abu.Sayyaf .10.WNI.Sempat.Dijamu.Gubernur.Sulu. negosiator melihat permasalahan dengan pandangan yang luas, sehingga tim negosiator tidak memandang Kelompok Abu Sayyaf hanya sebagai teroris dan selanjutnya dapat memasukkan unsur budaya, agama, serta pendidikan guna kelancaran negosiasi. Sebagai langkah preventif, Yayasan Sukma ke mu dian menjalin kerja sama dengan Atase Kebudayaan KBRI Manila. Sejumlah anakanak di Filipina Selatan juga diberikan beasiswa pendidikan oleh Yayasan Sukma. Kerja sama dengan Atase Kebudaya an KBRI Manila serta pemberian beasiswa pendidikan tersebut dilakukan setelah tim negosiator Yayasan Sukma menyadari kondisi serta keinginan masyarakat Filipina Selatan yang tidak memiliki akses pendidikan yang baik.

Tabel 4. De-eskalasi Konflik

\begin{tabular}{|l|l|l|}
\hline No. & $\begin{array}{l}\text { De-eskalasi } \\
\text { Konflik }\end{array}$ & Peristiwa \\
\hline 1. & $\begin{array}{l}\text { Changes in } \\
\text { parties }\end{array}$ & $\begin{array}{l}\text { Keterlibatan aktor non- } \\
\text { negara }\end{array}$ \\
\hline 2. & $\begin{array}{l}\text { Changes in } \\
\text { attitudes }\end{array}$ & $\begin{array}{l}\text { Perubahan } \\
\text { Kelompok Abu Sayyaf }\end{array}$ \\
\hline 3. & $\begin{array}{l}\text { Confidence } \\
\text { and security } \\
\text { building } \\
\text { measures }\end{array}$ & $\begin{array}{l}\text { Memudarnya rasa takut } \\
\text { dan curiga antar pihak dan } \\
\text { munculnya hubungan baru }\end{array}$ \\
\hline 4. & $\begin{array}{l}\text { Learning } \\
\text { processes }\end{array}$ & $\begin{array}{l}\text { Adanya persepsi baru yang } \\
\text { mengurangi ketidakpastian }\end{array}$ \\
\hline 5. & $\begin{array}{l}\text { Cultural } \\
\text { values }\end{array}$ & $\begin{array}{l}\text { Penyertaan unsur } \\
\text { kebudayaan oleh tim } \\
\text { negosiator Yayasan Sukma }\end{array}$ \\
\hline
\end{tabular}

Gambar 3.

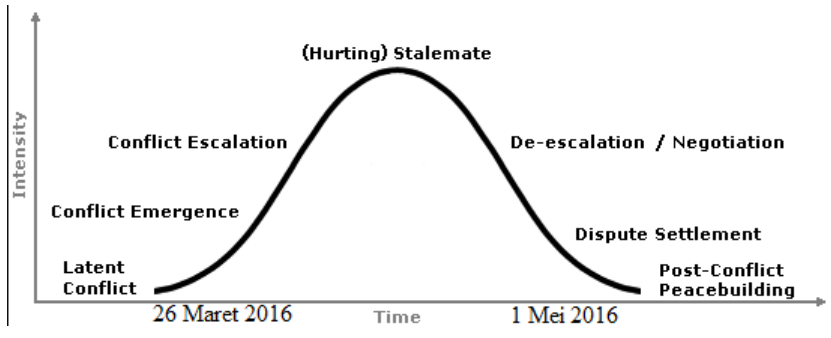

Sumber: Eric Brahm, 2003: 1

Peristiwa pembebasan 10 sandera WNI ABK kapal tunda Brahma 12 dan kapal 
tongkang Anand 12 dapat digambarkan dengan life cycle of conflict sesuai gambar 2.1. Dalam peristiwa pembebasan 10 sandera WNI, latent conflict sudah berlangsung sejak lama, yakni ketika masyarakat Filipina Selatan mengalami adanya perbedaan identitas dan ketidakadilan dengan masyarakat Filipina umumnya.

Sedangkan conflict emergence terjadi saat sepuluh ABK kapal tunda Brahma 12 dan kapal tongkang Anand 12 disandera oleh Kelompok Abu Sayyaf pada 26 Maret 2016. Selanjutnya, conflict escalation terjadi ketika Indonesia melibatkan aktor non-negara d alam usaha membebaskan sandera. Fase stalemate terjadi pada 9 April 2016, ketika terjadinya bentrok antara angkatan bersenjata Filipina dengan Kelompok Abu Sayyaf, yang kemudian menewaskan 18 tentara Filipina dan 5 anggota Kelompok Abu Sayyaf. ${ }^{55}$

Kegagalan angkatan bersenjata Filipina dalam menumpas Kelompok Abu Sayy af dan membebaskan sandera tersebut menunjukkan bahwa Indonesia perlu lebih mengandalkan aktor non-negara dibanding mengandalkan angkatan bersenjata Filipina. Sedan gkan dari sisi Kelompok Abu Sayyaf, bentrok tersebut telah melemahkan organisasi. Kelompok Abu Sayyaf perlu mengurangi jumlah sandera untuk meringankan beban. Hal tersebut sejalan dengan pernyataan narasumber penelitian yang menyatakan bahwa Kelompok Abu Sayyaf seringkali meninggalkan sanderanya apabila bentrok dengan angkatan bersenjata terjadi.

Kemudian tim negosiator Yayasan Sukma pun melakukan kontak dengan Kelompok Abu Sayyaf. Kontak tersebut diikuti dengan adanya unsur-unsur kebudayaan dan agama yang menjadi perwujudan pendekatan kemanusiaan oleh tim negosiator Yayasan Sukma. Kepercayaan pun didapat oleh tim negosiator Yayasan Sukma, dan hal tersebut menandakan de-eskalasi dalam peristiwa pembebasan 10

55 Indra, Putu Agung Nara. (2016). Tentara Filipina dan Abu Sayyaf Bentrok, 23 Tewas. Diambil 28 April 2020 dari: https://tirto.id/tentara-filipina-dan-abu-sayyafbentrok-23-tewas-Drp sandera WNI ABK kapal tunda Brahma 12 dan kapal tongkang Anand 12.

Negosiasi untuk membebaskan sandera kemudian dilakukan oleh tim negosiator Yayasan Sukma dan Kelompok Abu Sayyaf. Fase dispute settlement tercapai ketika sepuluh sandera ABK kapal tunda Brahma 12 dan kapal tongkang Anand 12 dibebaskan di depan rumah Gubernur Sulu, yang selanjutnya diterbangkan ke Indonesia. Post-conflict peacebuilding kemudian dilakukan dengan terjalinnya kerja sama antara Yayasan Sukma dengan Atase Kebudayaan KBRI Manila serta adanya pemberian beasiswa oleh Yayasan Sukma kepada anak-anak di Filipina Selatan.

\section{KESIMPULAN}

Penelitian ini berfokus pada multi-track diplomacy yang dilakukan oleh tim negosiator Yayasan Sukma. Tim negosiator Yayasan Sukma kemudian terjun langsung ke Filipina Selatan untuk membebaskan sandera. Pendekatan kemanusiaan serta perlibatan komunitas lokal menjadi kunci bagi tim negosiator Yayasan Sukma untuk membebaskan sandera. Dengan melibatkan komunitas lokal, tim negosiator Yayasan Sukma berhasil melakukan kontak langsung dengan Kelompok Abu Sayyaf. Setelah melakukan kontak langsung dengan Kelompok Abu Sayyaf, tim negosiator pun berhasil melakukan de-eskalasi konflik dan negosiasi dengan menggunakan unsur kebudayaan, agama, serta pendidikan. Secara historis, Kelompok Abu Sayyaf terbentuk dengan tujuan mendirikan pemerintahan Muslim di Filipina Selatan. Tujuan tersebut lahir dari adanya perbedaan identitas antara masyarakat di Filipina Selatan dengan masyarakat Filipina secara umum. Dengan adanya perbedaan identitas tersebut, masyarakat Filipina Selatan mengalami kekerasan kultural dan struktural yang selanjutnya menyebabkan minimnya akses kesejahteraan masyarakat Filipina Selatan.

Oleh karenanya, menjadi efektif ketika Indonesia dan Yayasan Sukma mengambil langkah pembebasan sandera melalui multi- 
track diplomacy yang menitikberatkan pada peacemaking dan dengan tujuan peacebuilding.

\section{DAFTAR PUSTAKA}

Arendt, H. (1962). The Origins of Totalitarianism. New York: Meridian.

Asril, S. (2016, May 2). Kompas.com. Diambil dari Kompas.com: https://nasional.kompas.com/read/2016/05/ 02/06362411/Negosiator.Sebut.Pembebasa n.10.WNI.Tanpa.Uang.Tebusan.Ini.Ceritan ya.

BBC. (2018, January 9). Philippines' Country Profile. Diambil 9 Mei 2020, dari BBC News: https://www.bbc.com/news/worldasia- 15521300

Brahm, E (2003, September 1). Conflict Stages. Diambil dari Kompas.com: https://www.beyondintractability.org/essay/ conflict_stages

Burgess, H., \& Burgess, G. M. (2016, October 16). Beyond Intractability. Diambil 9 September 2019, dari Beyond Intractability:

https://www.beyondintractability.org/moos/ multi-track-diplomacy

Creswell, J. W. (2010). Research Design Qualitative, Quantitative, And Mixed Methods Approaches. California: SAGE Publications, Inc.

Debora, Y., Adhi Bhaskara, I. L., \& Indra, P. A. (2016, Juni 17). Terlalu Naif Kalau Tanpa Uang Tebusan. Diambil 28 November 2019, dari tirto.id: https://tirto.id/terlalu-naif-kalau-tanpauang-tebusan-bliy

Dewi, P. R. (2019). The Use of Multitrack Diplomacy in The Liberation of 10 Indonesian Ship Crew From The Abu Sayyaf Group 2016. Andalas Journal of International Studies, 188-202.

Diamond, L., \& McDonald, J. (1996). Multi Track Diplomacy: A System Approach to Peace. Colorado: Kumarian Press.

Direktorat Jenderal Hukum dan Perjanjian Internasional Kementerian Luar Negeri. (n.d.). e-library Direktorat Jenderal Hukum dan Perjanjian Internasional Kemen terian Luar Negeri. Diambil 18 Mei 2020, dari Direktorat Jenderal Hukum dan Perjanjian Internasional Kementerian Luar Negeri: https://pustakahpi.kemlu.go.id/dir_dok/UU-
No.37.1999\%20-tentang-Hubungan-LuarNegeri.pdf

Faure, G. O. (2003). Negotiating with Terrorists: The Hostage Case. International Negotiation, 469-494.

Faure, G. O. (2011). Negotiating with political, ideological, and criminal terrorists. Jornadas secuestros y toma de rehenes por parte de grupos terroristas, 1 28.

Fellman, Z. (n.d.). Homeland Security \& Counterterorrism Program Transnational Threats Project. Diambil 12 Maret 2020, dari Center for Strategic \& International Studies: https://csisprod.s3.amazonaws.com/s3fspublic/legacy_files/files/publication/11112 8_Fellman_ASG_AQAMCaseStudy5.pdf

Freeman Spogli Institute for International Studies. (6, August 2018). Stanford Center for International Security and Cooperation. Diambil 12 Maret 2020, dari Stanford University:

https://cisac.fsi.stanford.edu/mappingmilita nts/profiles/abu-sayyaf-group

Goodin, R. E. (2006). What's Wrong With Terorrism. Cambridge: Polity.

Heywood, A. (2011). Global Politics. New York: Palgrave MacMillan.

Hranjski, H. (2019, January 26). Filipino Muslims Approve New Autonomous Region in Referendum. Diambil 9 Maret 2020, dari AP: https://apnews.com/b58dbb65b5304bbf9c7 b9bceff8d7e6f

Indra, P. A. (2016, April 10). Tentara Filipina dan Abu Sayyaf Bentrok, 23 Tewas. Diambil 28 April 2020, dari tirto.id: https://tirto.id/tentara-filipina-dan-abusayyaf-bentrok-23-tewas-Drp

Kementerian Pekerjaan Umum dan Perumahan Rakyat Sekretariat Jenderal Pusat Data dan Tekonologi Informasi. (2017). Buku Informasi Statistik 2017. Jakarta: Kementerian Pekerjaan Umum dan Perumahan Rakyat Sekretariat Jenderal Pusat Data dan Tekonologi Informasi.

McCains, M. J., \& Mullins, W. C. (2015). Crisis Negotiations: Managing Critical Incidents and Hostage Situations in Law Enforcement and Corrections. New York: Routledge. 
McDonald, J. W. (2003, September 21).

Beyond Intractability. Diambil 9 September 2019, dari Beyond Intractability: https://www.beyondintractability.org/essay/ multi-track-diplomacy

McDonald, J. W. (2012). The Institution of Multi-Track Diplomacy. Journal of Conflictology, 65-70.

Prasetyo, W. (2016, May 2). Tentang Uang Tebusan 50 Juta Peso untuk 10 WNI dan Jalur Pelayaran RI-Filipina. Diambil 28 Januari 2020, dari detik.com: https://news.detik.com/berita/d-

3201861/tentang-uang-tebusan-50-jutapeso-untuk-10-wni-dan-jalur-pelayaran-rifilipina

Wahjudi, G. (2003). Penanganan Aksi Teroisme Internasional di Filipina Bagian Selatan oleh Asean Tahun 2000-2001. Kerjasama Regional ASEAN Menghadapi Isu Terorisme Internasional, 85.

Wahono, T. (2016, May 2). Bebas dari Kelompok Abu Sayyaf, 10 WNI Sempat Dijamu Gubernur Sulu. Diambil 28 Januari 2020, dari Kompas.com: https://internasional.kompas.com/read/2016 /05/02/00483791/Bebas.dari.Kelompok.Ab u.Sayyaf.10.WNI.Sempat.Dijamu.Gubernur .Sulu

Wibisono, A. N. (2016). Kelompok Abu Sayyaf dan Radikalisme di Filipina Selatan: Analisis Organisasi Terorisme Asia Tenggara. Ilmu Ushuluddin, Volume 3, Nomor 1, 119-132.

Wilson, M. (2011). Toward a Model of Terrorist Behavior in Hostage-Taking Incidents. The Journal of Conflict Resolution, 406.

Yahya, A. N. (2020, March 3). Kompas.com. Diambil 18 Maret 2020, dari Kompas.com: https://nasional.kompas.com/read/2020/03/ 03/20325651/abu-sayyaf-minta-tebusanbebaskan-5-wni-mahfud-segera-lakukanpembahasan

Yayasan Sukma. (2018). About Us. Diambil 13 April 2020, dari Yayasan Sukma: https://yayasan-sukma.org/about-us

Zartmann, I. W., \& Faure, G. O. (2005). Escalation and Negotiation in International Conflicts. Cambridge: Cambridge University Press.

\section{BIOGRAFI}

Joshua, lahir di Jakarta pada 24 Mei 1998. Memiliki ketertatikan pada soft-power, studi perdamaian, studi identitas, dan budaya-budaya dalam Hubungan Internasional

Hasan Sidik merupakan pengajar pada Departemen Hubungan Internasional Universitas Padjadjaran yang memiliki ketertarikan mengkaji hukum Interna sional. 